\title{
PENGEMBANGAN BUKU AJAR MIKROBIOLOGI BERBASIS HASIL PENELITIAN EKSPLORASI DAN KARAKTERISASI BAKTERI PADA MAKANAN DAN MINUMAN
}

\author{
Ismi Nurul Qomariyah ${ }^{1}$, Trio Ageng Prayitno \\ ${ }^{1,2}$ IKIP Budi Utomo, Jl. Simpang Arjuno 14B Malang \\ E-mail: isminurul88@gmail.com
}

\begin{abstract}
Students need microbiology textbooks that contain the latest research results so that microbiological material is dynamic. The research problem is how is the form of developing microbiology textbooks based on research results that meet the criteria of eligibility or validity. The study aims to determine the form of development of microbiology textbooks based on research results that meet the criteria of eligibility or validity. This research is a development research using the Thiagarajan 4-D development model, which includes define, design and develop stages. The microbiology textbooks developed were tested for validity and attractiveness to microbiology material experts, instructional media experts, practitioners and a small group of students who had taken microbiology courses. The results showed that the research-based microbiology textbooks were declared feasible or valid by a team of experts, practitioners, and students. Research-based microbiology textbooks are unique in that they contain research work procedures in the laboratory so as to facilitate students to understand microbiology material and establish life skills.
\end{abstract}

Keywords: textbooks, microbiology, research results

\begin{abstract}
Abstrak: Mahasiswa membutuhkan buku ajar mikrobiologi yang memuat hasil penelitian terbaru sehingga materi mikrobiologi bersifat dinamis. Masalah penelitian adalah bagaimana bentuk pengembangan buku ajar mikrobiologi berbasis hasil penelitian yang memenuhi kriteria layak atau valid. Penelitian bertujuan untuk mengetahui bentuk pengembangan buku ajar mikrobiologi berbasis hasil penelitian yang memenuhi kriteria layak atau valid. Penelitian ini adalah penelitian pengembangan dengan menggunakan model pengembangan 4-D Thiagarajan, yang meliputi tahapan define, design dan develop. Buku ajar mikrobiologi yang dikembangkan diuji validitas dan daya tariknya kepada ahli materi mikrobiologi, ahli media pembelajaran, praktisi, dan sekelompok kecil mahasiswa yang telah menempuh mata kuliah mikrobiologi. Hasil penelitian menunjukkan bahwa buku ajar mikrobiologi berbasis hasil penelitian dinyatakan layak atau valid oleh tim ahli, praktisi dan mahasiswa. Buku ajar mikrobiologi berbasis hasil penelitian memiliki keunikan adalah memuat prosedur kerja penelitian di laboratorium sehingga memfasilitasi mahasiswa untuk memahami materi mikrobiologi dan membetuk kecakapan hidupnya (life skills).
\end{abstract}

Kata kunci: buku ajar, mikrobiologi, hasil penelitian

Mikrobiologi adalah matakuliah wajib di Program Studi Pendidikan Biologi IKIP Budi Utomo Malang. Mikrobiologi yaitu salah satu cabang ilmu dalam biologi yang mempelajari kehidupan mikroorganisme dan peranannya dalam kehidupan manusia. Berdasarkan Kerangka Kualifikasi Nasional Indonesia (KKNI), mikrobiologi yang merupakan ilmu dalam Biologi memerlukan pengaplikasian konsep dan prinsip didaktif dan paedagogis serta keilmuan biologi untuk menciptakan kecakapan hidup atau life skills bagi mahasiswa (Kurikulum KKNI IKIP Budi Utomo, 2018).

Kecakapan hidup bagi mahasiswa dapat tercipta melalui suatu pembelajaran berbasis penelitian. Pembelajaran berbasis penelitian adalah salah satu bentuk kegiatan pembelajaran student centered learning yang mengintegrasikan hasil riset atau penelitian 
dalam proses pembelajaran (Clark, 1997). Pembelajaran berbasis penelitian dapat dilakukan dengan penyediaan bahan ajar yang memuat hasil penelitian. Bahan ajar dapat berupa bahan tertulis maupun bahan tidak tertulis yang memuat informasi seperti materi-materi ajar dan prosedur kerja hasil pengalaman penelitian di laboratorium yang akan ditransfer kepada peserta didik (Majid, 2007).

Hasil observasi dan wawancara yang dilakukan peneliti pada bulan April 2018 menunjukkan bahwa $82,35 \%$ mahasiswa membutuhkan literatur untuk menguasai materi mikrobiologi. $76,48 \%$ mahasiswa menjawab yaitu buku ajar mikrobiologi yang ada belum memuat materi dari hasil penelitian. Dosen praktisi mikrobiologi di Program Studi Pendidikan Biologi IKIP Budi Utomo mengharapkan adanya bahan ajar mikrobiologi yang memuat materi mikrobiologi yang up to date dari hasil penelitian sehingga informasi tentang mikrobiologi bersifat dinamis.

Berdasarkan permasalah di atas maka solusi inovatif untuk menyelesaikan permasalah tersebut adalah pengembangan buku ajar mikrobiologi berbasis hasil penelitian. Buku ajar mikrobiologi berbasis hasil penelitian dikembangkan dengan model pengembangan bahan ajar Thiagarajan four$D$ yang terdiri dari tahap define, design, develop dan disseminate. Buku ajar mikrobiologi yang dikembangkan memuat materi dari hasil penelitian sebelumnya tentang Eksplorasi dan Karakterisasi Bakteri pada Makanan dan Minuman di Lingkungan Kampus IKIP Budi Utomo Malang. Rumusan masalah pada penelitian ini adalah bagaimana produk pengembangan buku ajar mikrobiologi berbasis hasil penelitian yang memenuhi kriteria valid atau layak. Dengan demikian, maka penelitian ini bertujuan untuk mengetahui produk pengembangan buku ajar mikrobiologi berbasis hasil penelitian yang memenuhi kriteria valid atau layak.

\section{HASIL}

\section{Define}

Permasalahan yang diperoleh peneliti

\section{METODE}

Penelitian ini merupakan jenis penelitian pengembangan (Research \& Development) buku ajar mikrobiologi berbasis hasil penelitian Ekplorasi dan Karakterisasi Bakteri pada Makanan dan Minuman di Lingkungan Kampus IKIP Budi Utomo Malang. Model pengembangan buku ajar mikrobiologi berbasis hasil penelitian yang digunakan yaitu model pengembangan Thiagarajan 3 tahapan, yang meliputi; tahap define (pendefinisian), design (perancangan) dan develop (pengembangan).

Buku ajar mikrobiologi berbasis hasil penelitian diujikan untuk mengetahui tingkat validitas dan daya tarik kepada ahli materi, ahli media pembelajaran dan praktisi mata kuliah mikrobiologi. Selanjutnya, buku ajar tersebut diujikan pada 15 mahasiswa yang dianggap sebagai satu kelompok kecil.

Analisis data yang digunakan dalam penelitian pengembangan ini yaitu dengan cara mengumpulkan informasi yang berupa data kualitatif seperti saran dan komentar dari para ahli dan praktisi serta hasil uji skala kecil. Analisis skor hasil validasi oleh para ahli dan uji skala kecil digunakan untuk mengetahui item-item apa saja yang dinilai pada buku ajar mikrobiologi berbasis hasil penelitian. Selanjutnya, skor dari hasil uji validitas dan uji skala kecil dihitung persentase tiap itemnya dengan mengunakan rumus sebagai berikut. Hasil perhitungan tersebut ditetapkan kriteria kevalidan (Masrur, Corebima, \& Ghofur, 2017).

$$
P=\frac{X}{X 1} \times 100 \%
$$

Keterangan:

$P=$ Presentase skor;

$X=$ Jumlah skor pilihan responden tiap item

$X I=$ Jumlah skor pilihan maksimal tiap item

saat melaksanakan tahap define sebagai berikut.

1. $82,35 \%$ mahasiswa cenderung dalam mengusai materi Mikrobiologi dengan 
cara membaca berbagai literatur, baik itu berupa buku teks maupun jurnal ilmiah hasil penelitin.

2. $76,48 \%$ mahasiswa menjawab buku ajar mikrobiologi yang ada belum memuat materi dari hasil penelitian.

3. Praktisi mikrobiologi mengharapkan adanya bahan ajar mikrobiologi yang memuat materi-materi ter-up to date dari hasil penelitian sehingga informasi tentang mikrobiologi bersifat dinamis.

\section{Design}

Buku ajar mikrobiologi berbasis hasil penelitian yang dikembangkan berjudul "Eksplorasi dan Karakterisasi Bakteri pada Makanan dan Minuman di Lingkungan IKIP Budi Utomo". Buku ajar memiliki spesifikasi produk substantif dan spesifikasi produk teknis. Spesifikasi produk substantif yaitu materi-materi yang termuat pada buku ajar mikrobiologi berbasis hasil penelitian. Sedangkan spesifikasi teknis buku ajar mikrobiologi berbasis hasil penelitian ini yaitu meliputi bagian awal, bagian isi dan bagian akhir.

Bagian awal terdiri dari kata pengantar, daftar isi, daftar tabel dan daftar gambar.Bagian isi meliputi materi $\mathrm{Bab}$ I sampai dengan Bab III. Bab I berisi materi struktur dan morfologi bakteri, reproduksi bakteri, klasifikasi bakteri, dan peran bakteri bagi kehidupan. Bab II memuat materi jenisjenis bakteri kontaminan pada makanan dan minuman. Bab III memuat materi jenis-jenis makanan dan minuman di lingkungan Kampus, alat dan bahan penelitian eksplorasi dan karakterisasi bakteri pada makanan dan minuman di lingkungan Kampus IKIP Budi Utomo Malang, metode eksplorasi dan karakterisasi bakteri pada makanan dan minuman di lingkungan Kampus IKIP Budi Utomo, serta hasil dan pembahasan. Bagian akhir buku ajar mikrobiologi berbasis hasil penelitian ini adalah kesimpulan, daftar rujukan dan riwayat penulis buku ajar.

\section{Develop}

Hasil uji validitas dan daya tarik buku ajar mikrobiologi berbasis hasil penelitian yang telah dikembangkan sebagai berikut.

Ringkasan hasil uji validitas dan uji skala kecil buku ajar mikrobiologi berbasis hasil penelitian dapat dilihat pada Tabel 1. Saran dan komentar ahli materi mikrobiologi yaitu (1) daftar rujukan agar ditambah sesuai dengan referensi yang terdapat pada isi materi, (2) halaman buku masih belum sesuai dengan syarat jumlah halaman buku hasil riset, dan (3) buku sudah bagus dan harap dikembangkan lagi agar lebih baik lagi.

Saran dan komentar yang diberikan oleh ahli media pembelajaran sebagai berikut. (1) Cover depan buku sudaha bagus, namun teks masih terlihat buram dan pecah. (2) Ukuran huruf nama penulis agar diperkecil sehingga proporsional. (3) Cover belakang sudah bagus, namun masih belum ada keterangan umum tentang isi buku yang dikembangkan. (4) Keterangan gambar sudah sesuai aturan penulisan, namun sumber gambar masih belum tampak. Saran dan komentar praktisi yaitu gambar pada buku agar diperbanyak lagi sehingga pembaca tidak bosan dan tambahkan pula soal evaluasi untuk mahasiswa.

Tabel 1. Ringkasan Hasil Uji Validitas dan Uji Skala Kecil Buku Ajar Mikrobiologi Berbasis Hasil Penelitian

\begin{tabular}{|l|c|c|c|}
\hline \multicolumn{1}{|c|}{ Uji Validitas } & $\begin{array}{c}\text { Hasil Validasi } \\
(\mathbf{\%})\end{array}$ & Keterangan & Keputusan Hasil Uji \\
\hline Ahli materi mikrobiologi & 96,05 & Sangat Valid & Tidak Revisi \\
\hline Ahli media pembelajaran & 97,00 & Sangat Valid & Tidak Revisi \\
\hline $\begin{array}{l}\text { Praktisi/dosen } \\
\text { matakuliah mikrobiologi }\end{array}$ & 96,43 & Sangat Valid & Tidak Revisi \\
\hline Uji skala kecil & 94,70 & Sangat Valid & Tidak Revisi \\
\hline
\end{tabular}


Tabel 1 di atas menunjukkan bahwa secara keseluruhan buku ajar mikrobiologi berbasis hasil penelitian dengan judul "Eksplorasi dan Karakterisasi Bakteri pada Makanan dan Minuman di Lingkungan IKIP Budi Utomo" dinyatakan valid dan tidak perlu adanya revisi.

\section{PEMBAHASAN}

Hasil penelitian menunjukkan bahwa buku ajar mikrobiologi berbasis hasil penelitian telah memenuhi kriteria valid dari segi materi dan media pembelajaran sehingga layak untuk digunakan pada pembelajaran mikrobiologi. Segi materi menunjukkan bahwa buku ajar mikrobiologi tersebut memuat hasil penelitian eksperimental dengan judul Eksplorasi dan Karakterisasi Bakteri Makanan dan Minuman Sekitar Kampus C IKIP Budi Utomo Malang yang merupakan karya original dari peneliti yang dilaksanakan pada tahap sebelumnya. Pernyataan di atas sesuai dengan hasil penelitian Pangastuti, Amin, \& Indriwati (2016) bahwa buku ajar yang baik adalah buku ajar yang dikembangkan harus karya milik sendiri atau original, tidak menimbulkan permasalahan SARA maupun diskriminasi Gender.

Buku ajar mikrobiologi berbasis hasil penelitian yang telah dikembangkan didesain seperti kebutuhan yang ditemukan pada tahap define. Substansi isi buku mikrobiologi didesain dengan memuat materi tentang bentuk bakteri, reproduksi bakteri, klasifikasi bakteri dan peran bakeri bagi kehidupan. Peran bakteri dalam kehidupan yang dijelaskan dalam buku mikrobiolog tersebut adalah peran bakteri dalam mengkontaminasi makanan dan minuman di sekitar Kampus IKIP Budi Utomo Malang. Selain itu, materi tentang bakteri sering dirasa paling susah bagi mahasiswa karena materi jenis dan klasifikasi bakteri yang begitu banyak.

Penyajian langkah-langkah atau prosedur kegiatan eksplorasi dan identifikasi bakteri pada makanan dan minuman pada buku ajar bertujuan untuk melatih mahasiswa dalam melakukan investigasi atau penyelidikan keberadaan bakteri pada makanan dan minuman. Oleh karena itu, desain dan bentuk buku ajar mikrobiologi hasil penelitian yang telah dikembangkan ini berbeda dengan desain dan bentuk buku dari hasil penelitianpenelitian pengembangan terdahulu. Hasil penelitian Kristiana, Amin, \& Lestari (2018) menunjukkan bahwa buku ajar yang telah dikembangkan berdasarkan hasil penelitian laboratoris belum memuat prosedur atau langkah-langkah untuk menentukan ekspresi gen pada sapi kembar berbasis Mikrosatelit. Penelitian yang dilakukan oleh Noor \& Asih (2016) menjukkan bahwa buku ajar yang telah dikembangkan belum memuat langkahlangkah untuk inventarisasi tanaman obat di suku Semendo. Begitu juga hasil penelitian terdahulu yang dilakukan oleh Habibi, Suarsini, \& Amin (2016) menunjukkan bahwa buku ajar mikrobiologi dasar yang telah dikembangkan belum membuat langkah-langkah kerja penelitian yang dilaksanakan di laboratorium.

Nuha, Amin, \& Lestari (2016) dalam penelitiannya menunjukkan bahwa buku ajar yang telah dikembangkan sudah memuat prosedur dalam melakukan penelitian evolusi dan filogenetik. Hasil penelitian Sukoco, Amin, \& Gofur (2016) menjelaskan bahwa buku ajar yang telah dikembangkan sudah memuat prosedur penelitian sehingga mempermudah mahasiswa dalam memahami materi yang berdasar pada pengalaman kerja penelitian di laboratorium. Hasil penelitian Pambudiono, Suarsini, \& Amin (2016) menunjukkan bahwa dalam buku ajar bioteknologi yang telah dikembangkan sudah memuat prosedur dalam melakukan penelitian logam berat Kadmium. Hasil penelitian Prayitno (2017) menunjukkan bahwa hasil pengembangan buku petunjuk praktikum mikrobiologi telah memuat langkah-langkah kegiatan praktikum mikrobiologi. Namun demikian, isi prosedur yang ada pada produk penelitian terdahulu tersebut tidak memiliki kesamaan dalam hal materi dengan hasil pengembangan buku ajar mikrobiologi berbasis hasil penelitian yang telah dikembangkan.

Namun, jika hasil penelitian pengembang 
produk ini dibandingkan dengan hasil penelitian yang dilakukan oleh Ulfa, Suarsini, \& Irawati (2017), Fidiastuti \& Rozhana (2016), Habibi, Suarsini, \& Amin, (2016a) maupun Lestari \& Hartati (2017) yang samasama melakukan uji keterbacaan produk pengembangan kepada mahasiswa dan mendapatkan kriteria valid. Maka produk hasil penelitian pengembangan ini memperoleh nilai kevalidan yang lebih tinggi dibandingkan produk hasil penelitian terdahulu. Hal ini terlihat dari hasil uji skala kecil produk pengembangan yaitu sebesar $94,70 \%$, sedangkan hasil uji keterbacaan dari hasil penelitian terdahulu sebesar $81,60 \%$ $86,55 \%$.

Buku ajar mikrobiologi berbasis hasil penelitian ini menunjukkan bahwa (1) materi yang disajikan berdasarkan dengan RPS mata kuliah mikrobiologi, (2) buku ajar mampu memberikan kesempatan pada mahasiswa untuk mengidentifikasi masalah dengan cara yang berbeda, (3) urutan penyajian materi dapat membantu mahasiswa dalam menguasai konsep dan (4) materi sesuai dengan tingkat berpikir mahasiswa. Pernyataan di atas sesuai dengan hasil penelitian Pratama, Amin, Suarsini, Biologi, \& Malang (2016) menjelaskan bahwa buku ajar yang dikembangkan dari hasil penelitian harus memuat kompetensi dasar yang harus dicapai oleh mahasiswa.

Berdasarkan urain di atas, maka keunggulan produk hasil penelitian pengembangan ini sebagai berikut. (1) Produk memuat langkah-langkah kegiatan penelitian untuk berinvestigasi pada bakteri makanan dan minuman sehingga produk pengembangan ini mampu memfasilitasi para mahasiswa untuk menemukan masalah, pengumpulan data, analisis data, dan menyimpulkan hasil investigasi yang berguna untuk mengatasi permasalahan kualitas makanan dan minumna. (2) Materi yang termuat pada produk pengembangan mampu memberikan inspirasi kepada mahasiswa untuk menemukan ide kreatif dan inovatif terhadap permasalah di masyarakat yang relevan dengan mikrobiologi.
Sedangkan kelemahan produk ini sebagai berikut. (1) Produk belum banyak memuat gambar-gambar yang sesua dengan teks materi. (2) Produk belum memuat soal evaluasi atau uji kompetensi. (3) Produk masih belum diuji pengaruhnya terhadap kompetensi mahasiswa sehingga perlu dilakukan uji pengaruh dengan metode quasi experiment dengan tujuan untuk mengetahui pengaruhnya terhadap Higher Order Thinking Skills (HOTS) mahasiswa.

\section{KESIMPULAN DAN SARAN}

\section{Kesimpulan}

Buku ajar mikrobiologi berbasis hasil penelitian dinyatkan layak dari segi materi dan media pembelajaran. Buku ajar yang telah dikembangkan memiliki keunikan yaitu memuat prosedur atau langkah kerja penelitian yang dilaksanakan di laboratorium sehingga mempermudah mahasiswa dalam memahami konsep materi mikrobiologi.

\section{Saran}

Produk penelitian yang telah dihasilkan yaitu buku ajar mikrobiologi berbasis hasil penelitian masih perlu diuji keefektifannya terhadap kemampuan berpikir mahasiswa dengan desain penelitian kuasi eksperimen sehingga produk hasil penelitian ini benarbenar layak untuk dipergunakan dalam pembelajaran mikrobiologi dan mampu memfasilitasi pemberdayaan berpikir kritis mahasiswa.

\section{DAFTAR RUJUKAN}

Clark B.R. 1997. The Modern Integration of Research Activities with Teaching and Learning. J.Higher Educ,1997Fidiastuti, H. R., \& Rozhana, K. M. (2016). Pengembangan Modul Matakuliah Mikrobiologi Melalui Biodegradasi Memanfaatkan Potensi Bakteri Indigen. Jurnal Pendidikan Biologi Indonesia, 2(2), 125-132.

Habibi, M. W., Suarsini, E., \& Amin, M. (2016a). Pengembangan Buku Ajar Matakuliah Mikrobiologi. Jurnal Pendidikan: Teori, Penelitian, Dan 
Pengembangan, 1(5), 890-900.

Habibi, M. W., Suarsini, E., \& Amin, M. (2016b). Pengembangan Buku Ajar Matakuliah Mikrobiologi Dasar. Jurnal Pendidikan: Teori, Penelitian, Dan Pengembangan, 1(5), 890-900.

Kristiana, E., Amin, M., \& Lestari, U. (2018). Pengembangan Buku Ajar Ekspresi Gen Menggunakan Penelitian Deteksi dan Identifikasi Conception Rate Gene Sapi (Bos Taurus) Kembar Berbasis Mikrosatelit. Jurnal Pendidikan: Teori, Penelitian, Dan Pengembangan, 3(3), 302-311.

Lestari, P. B., \& Hartati, T. W. (2017). Analisis Pengembangan Bahan Ajar Mikrobiologi Berbasis Inkuiry di IKIP Budi Utomo Malang. BIOEDUKASI, 10(2), 1-6.

Masrur, H., Corebima, A. D., \& Ghofur, A. (2017). PENGEMBANGAN BUKU SUPLEMEN MUTASI GEN PADA MATAKULIAH GENETIKA. Jurnal Pendidikan, 2(9), 1160-1167.

Noor, R., \& Asih, T. (2016). Pengembangan Buku Ajar pada Kuliah Ekologi Tumbuhan melalui Inventarisasi Tanaman Obat di Suku Semendo Kecamatan Way Tenong Lampung Barat. BIOEDUKASI, Jurnal Pendidikan Biologi, 7(2), 114-120.

Nuha, U., Amin, M., \& Lestari, U. (2016). Pengembangan Buku Ajar Berbasis Berbasis Penelitian Evolusi dan Filogenetik Molekuler untuk Matakuliah Evolusi di Universitas Jember. Jurnal Pendidikan: Teori, Penelitian, Dan Pengembangan, 1(9), 1791-1796.

Pambudiono, A., Suarsini, E., \& Amin, M. (2016). Pengembangan Buku Ajar Bioteknologi Berbasis Penelitian Bioremidiasi Logam Berat Kadmium Untuk Mahasiswa S1 Biologi Universitas Negeri Malang. Jurnal Pendidikan: Teori, Penelitian, Dan Pengembangan, 1(2012), 1077-1085. Retrieved from http://journal.um.ac.id/index.php/jptpp

Pangastuti, A., Amin, M., \& Indriwati, S. E.
(2016). Pengembangan Buku Ajar Biologi Sel Dengan Pendekatan Bioinformatika. Jurnal Pendidikan: Teori, Penelitian, Dan Pengembangan, l(1), 116-121. https://doi.org/10.17977/JP.V1I2.6105

Pratama, M. A., Amin, M., Suarsini, E., Biologi, P., \& Malang, P. N. (2016). Pengembangan Buku Ajar Matakuliah Bioteknologi Di Universitas Jember. Jurnal Pendidikan, 1(10), 1987-1992.

Prayitno, T. A. (2017). Pengembangan Petunjuk Praktikum Mikrobiologi Program Studi Pendidikan Biologi. Jurnal Biota, 3(1), 31-37.

Sukoco, R. M., Amin, M., \& Gofur, A. (2016). Pengembangan Buku Ajar Tabm Berbasis Penelitian Untuk Mahasiswa S1 Jurusan Biologi Universitas Negeri Gorontalo. Jurnal Pendidikan: Teori, Penelitian, Dan Pengembangan, 1(6), 1098-1103.

Ulfa, A., Suarsini, E., \& Irawati, M. H. (2017). Pengembangan Buku Ajar Mikrobiologi Tentang Bioreduksi Merkuri Bagi Mahasiswa Pendidikan Biologi. Jurnal Pendidikan: Teori, Penelitian, Dan Pengembangan, 2(1), 42-49. 